Joanna Rutkowiak

E-MAIL: joannarut1@gmail.com

Karolina Starego

Uniwersytet Gdański

E-MAIL: karolina.starego@ug.edu.pl

\title{
Tło i ruch - rozmowa o polityczności edukacji. Profesor Joanna Rutkowiak w rozmowie z doktor Karoliną Starego
}

\section{STRESZCZENIE}

Rozmowa dotyczy szeroko pojętych, politycznych kontekstów edukacji oraz problemu jej polityczności i upolitycznienia. Koncentrując się zarówno na współczesnych zjawiskach, takich jak neoliberalizm, postprawda, brutalizacja i faszyzacja przestrzeni publicznej, oraz przeszłych, takich jak transformacja ustrojowa, rozmówczynie starają się wskazać nie tylko na związane z nimi edukacyjne zaniedbania, ale również określić, w jakim kierunku powinien pójść odpowiedzialny społecznie i wrażliwy na polityczny kontekst edukacji, teoretyczny namysł pedagogiki.

SŁOWA KLUCzowE: polityczność edukacji, upolitycznienie edukacji, neoliberalizm, transformacja ustrojowa, postprawda

Karolina Starego: Naszą rozmowę wokół problemu polityczności edukacji chciałabym rozpocząć od artykułu, który ukazał się w 1995 roku pod tytułem Polityczność a upolitycznienie wychowania, w którym Pani Profesor wspólnie z Profesor Marią Szczepską-Pustkowską wprowadziły pojęcie „polityczności” w obszar rodzimej refleksji pedagogicznej. Tekst ten został napisany w szczególnym momencie. Obie kategorie zostały bowiem podjęte w kontekście transformacji ustrojowej. To właśnie między innymi ze względu na ówczesne „transformacyjne” tendencje do odpolityczniania zróżnicowanych aspektów rzeczywistości społecznej jednym z głównych celów artykułu stało się rozdzielenie i precyzyjne zdefiniowanie tytułowych kategorii. Najogólniej rzecz ujmując, „polityczność” rozumiana jest tam jako uniwersalny wymiar myślenia o wychowaniu, podczas gdy polityka - jako „określona dziedzina relacji państwa - prawa - społeczeństwa - jednostki". Moje pierwsze pytanie dotyczy współczesnych przejawów polityczności edukacji. Innymi słowy, chciałabym zapytać, z jakimi „merytorycznymi kierunkami” upolitycznienia mamy, zdaniem Pani Profesor, obecnie do czynienia? 
Joanna Rutkowiak: Zacznijmy temat od dawnego tekstu, w którym polityczność rozumiem jako szeroko pojęty, w pewnym sensie organiczny, związek sprawowania władzy i edukacji. Wynika on - w dużym uproszczeniu - z wzajemnych, zawsze napiętych, relacji ludzi, tych, „którymi się włada” i „władających”. Natomiast upolitycznienie rozumiem jako podporządkowanie koncepcji wychowania określonej, jednej koncepcji uprawiania władzy, wynikającej z jakości uprawianej polityki.

Podtrzymując ten punkt widzenia zwracam się do Pani pytania o współczesne przejawy polityczności i widzę rzecz następująco: Jeden element zmiany dostrzegam w tym, że zasygnalizowane sprawy bardzo zyskały na aktualności. Po przełomie transformacyjnym zagadnień upolityczniania i polityczności albo nie podejmowano, albo łączono je przede wszystkim ze sferą gospodarki. Wielu edukatorów, być może przede wszystkim nauczycieli, głosiło wówczas hasła apolityczności jako stanu pożądanego, a łączenie polityki z edukacją interpretowano jako szkodliwe; za takim sposobem myślenia kryło się - jak sadzę - nieodróżnianie odpowiednich zjawisk i pojęć. Powodowało to, że traktowano polityczność jako upolitycznianie, co łączono z negatywnie wartościowanym stanem z poprzedniej epoki, z realnym socjalizmem, pomijano natomiast bieżącą zmianę w jakości upolityczniania edukacji, bądź szerzej - uniwersalny charakter tego zjawiska.

Inny element zmiany dostrzegam $\mathrm{w}$ tym, że w czasie transformacyjnym sprawy polityczne łączono przede wszystkim z obszarem gospodarczym. Przyjęto, że zmiana ustrojowa pociąga za sobą zmianę charakteru gospodarki, przede wszystkim jej urynkowienie i z niemałą dozą zapału uprawiano odpowiednie praktyki. Refleksja przyszła nieco później, co nie znaczy, że dostrzeżono możliwą (rynkową, a merytorycznie - neoliberalną) analogię między przemianami zachodzącymi w sferze edukacji i gospodarki. Takie myślenie powoli dojrzewało w nas.

Zmiana, która zaszła od tamtego czasu polega na tym, że upolitycznianie, z jego neoliberalnym ukierunkowaniem, o którym zapewne jeszcze pomówimy, ogarnęło wszystkie dziedziny życia - sztukę, sport, zdrowie, media, kulturę popularną, naukę... Dotknęło to edukację w ten sposób, że na jej obszarze zwielokrotniły się wpływy; upolitycznienie jest bowiem wzmacniane i niejako potęgowane przez odpowiednie naciski wywierane na współistniejące dziedziny życia, które ulegają analogicznej presji. Tworzy to swojego rodzaju totalność upolityczniania neoliberalnego, w jakim zanurzona jest także i edukacja.

Ważny aspekt sprawy dotyczy zmiany środków i narzędzi oddziaływania. Jako szczególnie znaczącą widzę tutaj aktywność mediów oraz funkcjonowa- 
nie zjawiska postprawdy. Wielozmysłowa i wielokanałowa siła mediów, ich dynamika i wypracowane techniki oddziaływań czynią współczesne media potężnym instrumentem upolityczniania, ale też są szansą uświadamiania sobie, na czym polega polityczność, także edukacji. O ile ta kwestia jest już w pewnym stopniu rozpracowana przez znawców, o tyle sprawa postprawdy jako środka upolityczniania właściwie nie jest jeszcze przemyślana. Jesteśmy na początku drogi. Łączy się ona z kwestią prawdy i z klasycznymi pytaniami - czymże ona jest, a na tym tle - czym jest postprawda i jak ona oddziałuje na ludzi.

Ten nowy fenomen uderzył w społeczeństwa w latach 90., a już w 2016 Oxford Dictionaries ustanowiło „postprawdę” słowem roku. Przyjęto, że odnosi się ona do okoliczności, w jakich fakty tracą swoje znaczenie dla kształtowania opinii, przy równoczesnym wynoszeniu roli przekonań i emocji. Oznacza to, że prawda (przy całej różnorodności jej interpretowania) traci na znaczeniu, rośnie natomiast rola pozoru, akceptacji dla nieuzasadnianych zmian opinii i dla kłamstwa, którego się już nie potępia.

Nie pojmuję więc postprawdy jako epoki, rozumiem ją natomiast jako zjawisko kulturowe, a dokładniej, jako współczesne narzędzie manipulacji, które niejako uzyskało legitymizację przez coraz szersze używanie, ale i przez umieszczenie definicji w prestiżowym słowniku. Chociaż postprawda rozkwita na obszarze polityki, to - moim zdaniem - stanowi ona także narzędzie upolityczniania edukacji. Dzieje się to przede wszystkim drogą kolonizowania języka, co sprzyja uprawianiu dowolnych zmian sensów i znaczeń; ostatnio widzimy to w obszarze uprawiania „polityki historycznej”.

K.S.: Z jednej więc strony neoliberalizm - jak Pani Profesor podkreśliła, nadal można mówić o totalnej kolonizacji języka i racjonalności - i z drugiej postprawda, rozumiana jako narzędzie znaczeniowej manipulacji. Te dwa fenomeny są jednak połączone na jeszcze innym poziomie, poza tym, o którym mówiła Pani Profesor. Postprawda może być bowiem postrzegana nie tylko jako narzędzie, ale również jako konsekwencja dominacji racjonalności neoliberalnej. Jeśli na neoliberalizm spojrzymy z nieco innej perspektywy, a mianowicie jako na kres panowania elit symbolicznych, to postprawda będzie się jawić jako nowa racjonalność, w której zanikają uprzywilejowane - a więc związane z pozycją, kapitałem kulturowym i społecznym - sposoby patrzenia na rzeczywistość. Neoliberalizm, ze swoim zuniwersalizowanym kryterium pomiaru, jakim jest rynek, dokonuje bowiem pewnego fundamentalnego zrównania tam, gdzie występują różnice i nierówności kulturowe. W takim ujęciu kategoria postprawdy może naświetlić problem konfliktu, który da się określić - być może nazbyt ogólnie - jako konflikt mię- 
dzy elitami a masami. Konflikt ten najwyraźniej ujawnił się bowiem dopiero wtedy, kiedy tak zwane masy uzyskały możliwość artykulacji własnych żądań politycznych oraz fundamentalną dla procesów politycznych sprawczość polityczną, często elitarystycznie określaną mianem populizmu. Jego zaostrzenie bardzo wyraźnie zbiegło się w czasie z pojawieniem się $\mathrm{w}$ sferze publicznej głosu tych, którzy do tej pory głosu nie mieli, albo których głos był uciszany przez liberalne elity symboliczne. Innymi słowy mówiąc, kategoria postprawdy pojawiła się dokładnie wtedy, kiedy tak zwane masy uzyskały głos. W takim ujęciu właśnie postprawda może być synonimem zmierzchu panowania elit symbolicznych.

J.R.: W to wątpię. Wydaje mi się, że elity, no raczej tak zwane elity, czyli ci, którzy sami do elit siebie zaliczają, używają języka postprawdy. Sądzę, że język postprawdy staje się językiem uniwersalnym, zarówno językiem mas, jak i językiem elit. Problemem dla mnie jest to, że te grupy społeczne wzajemnie uczą się od siebie języka postprawdy. Tak zwane elity zauważają, że posługiwanie się takim językiem pozwala im zdobyć pewną popularność wśród tak zwanych mas, krótko mówiąc - uprawiać populizm. Natomiast masy zauważają, że jest to ten język, którym posługiwać się „należy”, a więc należy uczyć się go od elit jako wzorca języka skutecznego.

K.S.: Czyli raczej nie jest to symptom jakiejś zmiany w przestrzeni symbolicznej, który jednocześnie stanowi definicję tego, co się dzieje we współczesnym świecie zachodnim?

J.R.: Moim zdaniem nie tylko we współczesnych krajach zachodnich. Wydaje się, że postprawdę traktuje się jako skuteczny środek działań pragmatycznych, poręczne narzędzie, którym posługują się różni ludzie, w różnych miejscach i sytuacjach. Zastanawiające jest to, jak szybko rozprzestrzenia się używanie tej techniki. Co ważne, w odróżnieniu od tradycji klasycznego definiowania prawdy, z arystotelesowską zgodnością myśli i rzeczywistości, która miała w sobie wymiar etyczny, niejako powinność etyczną, funkcjonowanie współczesnej postprawdy staje się drogą do akceptacji nieprawdy, do akceptacji zła, jeśli zgodzimy się, że naruszanie prawdy jest złem. Ta zmiana zawiera w sobie mocny akcent etyczny, co jednakże trzeba by rozpatrywać z większą subtelnością, z uwzględnieniem kwestii relatywizmu jako nienowej doktryny filozoficznej.

K.S.: Mówienie prawdy w przestrzeni publicznej posiadało zatem wymiar etyczny. Kiedy zdaniem Pani Profesor zabieranie głosu w przestrzeni publicznej wiązało się z etyczną odpowiedzialnością, a mówienie prawdy postrzegane było w kategoriach obowiązku? Czy rzeczywiście był taki moment, czy to zapoznany obecnie ideał? 
J.R.: Momentu nie potrafiłabym określić. Natomiast słownikowe zdefiniowanie postprawdy w określonym czasie odebrałam jako rodzaj aprobaty, wyrażonej przez przyjęcie zjawiska do zasobów językowych $\mathrm{w}$ formule terminu. Zawartość słowników traktuje się w kulturze jako fakty ważkie, przyjmuje się, że słownikowa obecność oddaje niejako pozycję zjawiska. Słownikowe zaistnienie postprawdy dodało jej rangi, gdyż nie odbiera się jej już jako „wypadku przy pracy” bądź werbalnego wybryku mówcy (najczęściej polityka), który odrzuca etyczną odpowiedzialność, mówi coś zależnie od okoliczności i w ten sposób traktuje język jako skuteczna metodę własnego działania. Obecnie jest to bodaj uznawana metoda działania.

K.S.: To prawda, za legitymizacją poszło uznanie.

J.R.: Właśnie, sadzę, że to był punkt znaczący nie tylko formalnie, ale też i etycznie. Być może była to legitymizacja więcej niż językowa, gdyż również etyczna.

K.S.: Z drugiej jednak strony, jeśli przyjrzymy się refleksji politycznej, począwszy właściwie już od starożytności i sporu Sokratesa/Platona z sofistami, konflikt między zwolennikami retoryki a obrońcami obiektywnej prawdy systematycznie się odradza. Jest coś symptomatycznego w tym, że spór między „politycznymi relatywistami” a „obiektywistami” był i jest jednym z głównych tematów myśli politycznej. Jak pisze w swojej książce W. Marzec, reakcja na rebelię, a więc polityczne przebudzenie mas, które wiąże się w pierwszej kolejności z zakwestionowaniem reprodukcji politycznej arbitralności i tym samym jest podważeniem tego, co uchodzi za obiektywną prawdę, pociąga za sobą, w filozofii, teorii i eseistyce politycznej, elitarystyczną delegitymizację głosu ludu. W takim ujęciu, wiązana z prawdą kwestia etycznej odpowiedzialności, bardziej niż wyznacznikiem działania w przestrzeni publicznej, jest sposobem na legitymizację supremacji głosu elit. Patrząc $\mathrm{z}$ tej perspektywy jest zatem coś specyficznego w kategorii postprawdy. Stałabym chyba nadal na stanowisku, że sama ta kategoria ma funkcję polityczną.

J.R.: Zdecydowanie ma, i to pracuje na różnych poziomach, w różnych punktach życia społecznego. Pośrednio zaznacza się też w edukacji i w polityczności edukacji.

K.S.: Wracając do wątku transformacji ustrojowej i przemian po 1989 roku w Polsce, wydaje mi się, że warto odnotować, iż w kontekście transformacji fenomeny neoliberalizmu i postprawdy bardzo specyficznie się u nas mają. Lata 9o. to nie tylko tendencja do odcinania się od wszystkiego co kojarzyło się z systemem realnego socjalizmu - w tym z politycznością i upolitycznieniem, ale również legitymizacja i naturalizacja neoliberalizacji róż- 
nych obszarów życia społecznego. Elity liberalne są bez wątpienia uwikłane $\mathrm{w}$ winę. Przez prawie dwa dziesięciolecia sprzeciw wobec neoliberalnego myślenia i działania w różnych obszarach życia społecznego właściwie się nie pojawiał. Co więcej, w ujęciu niektórych teoretyków, z którymi się zgadzam, to za sprawą "ojców transformacji” neoliberalizm tak gładko i bez tarcia trafił do polskiego kontekstu.

J.R.: Łatwo jest tak powiedzieć po fakcie. Ja - z jednej strony - zgadzam się z tymi tezami, ale z drugiej - zastanawiam się nad kontekstem ówczesnych wydarzeń. Myślę o tym, co było wówczas możliwe, a co niemożliwe, jaką ludzie mieli wiedzę, a jakiej nie mieli. O ile wiem, w obszarze ekonomii uprawiano wówczas przede wszystkim problematykę mikro jako taktyczną, natomiast makroekonomia, jako podejście strategiczne, była traktowana jako dziedzina dla romantyków, marzycieli, a nie dla realistów, co bardzo utrudniało podejmowanie racjonalnych decyzji. Działały też zewnętrzne naciski na Polskę z powodu jej zadłużenia.

K.S.: Kontynuując wątek, wydaje się, że w Polsce mamy symboliczne elity liberalne, które mają swoją "historię neoliberalną”, a więc entuzjastyczną i afirmatywną legitymizację neoliberalizmu, i które posługują się kategorią postprawdy niczym orężem dyskwalifikującym przeciwnika. I z drugiej, „elity państwowe”, które z postprawdą są łączone, i które - żeby oddać sprawiedliwość - cynicznie wykorzystują egalitarystyczny potencjał postprawdy i ludowe przebudzenie. Czy Pani Profesor by się zgodziła z tym podziałem?

J.R.: To jest podział o walorach estetycznych, ale ja troszkę $w$ ten podział wątpię, ponieważ sądzę, że trudno dziś o czyste elity symboliczne. Elity polityczne mają tym bardziej zamglone oblicze, a nadzieja na „czystą grę" postprawdą jest też płonna. Dlatego jestem zdania, że próba takiego wyrazistego ujęcia tej sprawy jest bodaj niemożliwa. Postprawda grasuje i wciska się w różne szczeliny życia społecznego. Podam jeden przykład dotyczący owej niejednoznaczności. Słyszałam ostatnio wypowiedź uznanej akademickiej humanistki, która mówiła o tym, jak na początku lat 9o. zajęła się z wielkim zapałem zagadnieniem rynkowej promocji nowej na naszym rynku margaryny. Jaka to jest działalność? Czy mamy tutaj do czynienia z cynizmem, czy z afirmacją neoliberalizmu? Czy mówimy o elicie liberalnej, czy o ludziach neoliberalizmu?

K.S.: Wróćmy zatem na moment do pytania o winę symbolicznych elit liberalnych. Kilkadziesiąt lat po transformacji, idea demokracji, do której realizacji dążono okazała się demokracją w stylu zachodnim, a więc demokracją w bliskim sojuszu z neoliberalizmem, głuchą na nierówności i w gruncie rze- 
czy formalną, której przedrostek nie odnosi się do władzy żadnego demosu tylko wąsko pojętych elit. Jak to było możliwe?

J.R.: W tym miejscu sięgnę do literatury pięknej, bo ostatnio bliskie mi jest hasło sformułowane w obszarze literaturoznawstwa, że dobrze się myśli literaturą. Czytam dużo reportaży, szczególnie polskich reportaży społecznych. Znakomici autorzy, bardzo dobre teksty, do których będę się odwoływać. Wydaje się, że łatwo jest potępiać ten kierunek zmian transformacyjnych, który przyjęliśmy, ale trzeba pamiętać, jak bardzo byliśmy wtedy spragnieni demokratycznej zmiany, a wydawało się, że możliwy jest jeden jej kierunek z przejściem na gospodarkę wolnorynkową i naśladowanie krajów, które na tej drodze osiągały sukcesy. Nie zauważaliśmy natomiast, nie tylko my - pedagodzy, ale również i liczni ekonomiści, że charakter owej gospodarki rynkowej gwałtownie zmieniał się w latach 8o. i że zmieniała się też demokracja. Inaczej mówiąc, nie dostrzegaliśmy przejścia od liberalizmu do neoliberalizmu zarówno w aspekcie gospodarczym, jak i politycznym.

Nie było refleksji nad tym, że zachodnia gospodarka kapitalistyczna absolutnie zmieniła swoje meritum, a my, uwiedzeni hasłami „kapitalizm” i „wolny rynek" nie zadawaliśmy pytań - jaki wolny rynek, jaki kapitalizm. Jednym z nielicznych dostrzegających te problemy był prof. S. Kowalik, który nieco później zwracał uwagę na zapis obecny w konstytucji 1997, który przypomnę: „Społeczna gospodarka rynkowa oparta na wolności, wolności gospodarczej, własności prywatnej, oraz solidarności, dialogu i współpracy partnerów społecznych stanowi podstawę ustroju gospodarczego". Tę formułę mamy w konstytucji po dziś dzień, ale praktyka życia jest inna. Nie dostrzeżono, że gospodarka korporacyjna uniemożliwia społeczną gospodarkę rynkową oraz to, że korporacje stają się graczami nie tylko gospodarczymi, ale też politycznymi.

Z tym łączy się wątek, który A. Bielik-Robson nazwała śmiercią ojców, czy uśmiercaniem ojców. Nie całkiem zgadzam się z nim jako sprawą pokoleniową, ponieważ nie wszyscy ojcowie dorobili się na neoliberalizmie. Mamy przecież teraz wielu starych biednych emerytów, to są ludzie, którzy jako grupa wiekowa powinni być $\mathrm{w}$ dobrej kondycji, a nie są. Zarazem mamy wielu „chłopców Mordora”, tych rodzimych Chicago boys, którzy widzą swoje korporacyjne prace, zajęcia, zawody jako źródło dochodów i... niewiele więcej. Taki sposób myślenia przenosi się już na brać studencką, a nawet na uczniów, którzy decydują o swojej przyszłości kierując się głównie kompasem wysokości przyszłych zarobków.

My, jako edukatorzy, ale nie dotyczyło to całego środowiska pedagogicznego, długo nie dostrzegaliśmy tego zwrotu. Najpierw upajaliśmy się (i słusznie) zmianą ustrojową, polubiliśmy słowo „transformacja”, które bodaj było 
nadużywane, a jednocześnie przestaliśmy zauważać, w jakim kierunku poszła zmiana. Mam nam za złe, że wtedy kiedy już to dostrzegliśmy, już to było wyraźne, niemała część środowiska interioryzowała neoliberalny trend, poddając się neoliberalnym jakościom.

Kiedy w roku 1999 wprowadzano reformę szkolną z zewnętrznymi, zerojedynkowymi, odtwórczymi egzaminami testowymi, stanowiącymi rdzeń kształcenia reproduktywnego, wtedy my prawie nie protestowaliśmy, a nawet zdobiliśmy ten cios w kształcenie młodych nadziejami na obiektywizację ustalania wyników nauczania. Taki sam sposób myślenia przyjął się w uczelniach, a my ciągle nie przepracowaliśmy tego problemu. Zaglądam z tęsknotą do książki A. Ledera Prześniona rewolucja, gdzie on też mówi o nieprzepracowanych tematach dotyczących polskiego mieszczaństwa, ziemiaństwa i chłopstwa. Jestem zdania, że trzeba by dołączyć do nich nasz problem, a mianowicie problem edukacji. Tymczasem my przyjęliśmy określoną jej jakość nie zastanawiając się, na czym ona właściwie polega i ciesząc się podobieństwem do zachodnich rozwiązań. Obecnie nie tylko mamy zaległości w refleksji, ale sami popadliśmy w jakość neoliberalną. Zastanawia mnie chociażby to, w jaki sposób młodzi akademicy potrafią mówić o swojej pracy; oto pytam człowieka, o czym pisze artykuł, a on mi odpowiada, za ile punktów. To wyraża stosunek do tematu neoliberalnego, kiedy i edukatorzy, i edukowani w niemałym stopniu interioryzują i naturalizują zasady neoliberalne uznając, że skoro jest to tendencja szeroko rozlana, to należy się w niej osadzić bez rozważania skutków.

K.S.: Dotykamy zatem tutaj problemu edukacji i odpowiedzialności pedagogów za kierunek zmian.

J.R.: Braku czuwania nad kierunkiem zmian i braku sprzeciwu.

K.S.: Nie zwracano zatem należytej uwagi na to, co się działo w latach 90., że tylnymi drzwiami niejako, dostawała się do naszego sposobu myślenia racjonalność neoliberalna? Myślano o demokracji społecznej etycznej, demokracji, w której wszyscy chętnie biorą udział i podejmują decyzje polityczne...

J.R.: Pamiętajmy, że byliśmy jej szalenie spragnieni.

K.S.: Dlaczego nie zdawano sobie sprawy, mówię tu o przedstawicielach dyscyplin społecznych, że również w krajach zachodnich wyglądało to nieco inaczej, a więc odbiegało znacząco od ideału?

J.R.: Wydaje mi się, że nie mieliśmy należytej wiedzy i wyobraźni. To jednak były dwa duże zwroty, spotęgowane, gdyż nakładające się na siebie: na świecie liberalizm przechodził w neoliberalizm, a u nas „socjalizm” przechodził w kapitalizm, który wyobrażaliśmy sobie jako liberalny, podczas gdy on już był neoliberalny. Objęły nas obydwa te zwroty naraz, co oznaczało głę- 
boką zmianę. Trzeba by naprawdę bardzo dobrych analityków, żeby ją rozszyfrować i wizjonerów społecznych, żeby stworzyć projekty sensownych rozwiązań, no i bojowników walczących o sprawę. Czy byli tacy?

Niestety, ten wątek nieomal pomija K. Modzelewski w swojej znakomitej książce Zajeździmy kobyłę historii..., gdzie najpierw napisał o walce solidarności, a później o negatywnych konsekwencjach zmiany systemowej dla tych, którzy właściwie ją wywalczyli. Brakuje w tym analiz stanów mentalnych oraz uwzględnienia zewnętrznych nacisków, jakim podlegała ówczesna Polska.

K.S.: Czy zatem tym, o co można mieć żal do pedagogów jest brak krytycyzmu wobec tego co się działo?

J.R.: Było niemało fragmentarycznych krytyk, natomiast zabrakło spojrzenia „z lotu ptaka”, ale ono nie było łatwe. Paradoksalnie, do uprawiania takiego spojrzenia mogły mobilizować kontakty z nauczycielami, którzy widzieli z bliska edukacyjną codzienność i mogli - gdyby ich posłuchać - wysuwać tematy do szerszych interpretacji sytuacji, jednak tego nie uprawialiśmy. Kontakty środowiska akademickiego z nauczycielami osłabły i zastanawiająca wydaje się być geneza tego stanu. Zarazem trzeba powiedzieć, że nie wszyscy nauczyciele byli radzi sygnałom na temat neoliberalnego uzależnienia edukacji. Opowiem o dwóch wydarzeniach z okresu po ukazaniu się książki, którą napisałyśmy wspólnie z Panią Profesor E. Potulicką. Zapraszano nas wówczas tu i ówdzie na rozmowy o książce, powtarzała się w tych rozmowach jedna wypowiedź czytelnicza: „ta książka otworzyła mi oczy”. Zaproszono mnie kiedyś do dwóch szkół trójmiejskich, gdzie autorskie spotkania przebiegły różnie. W obydwu był sprzeciw przeciwko mojej interpretacji, a różnica była taka, że w jednej szkole, w której spędziłam dwie godziny głównie na ostrych dyskusjach, ponieważ nauczyciele powątpiewali w neoliberalne uwikłania edukacji, po kilku dniach zaproszono mnie na dalszy ciąg i wtedy spędziłam w szkole 6 godzin na rozmowie, w toku której analizowaliśmy zawiłości kwestii. Natomiast w drugiej szkole dyskusja była mniej gorąca, padła też zapowiedź kontynuowania spotkania, do czego jednak nie doszło. Odniosłam wrażenie, że część nauczycieli chciała poddawać refleksji to, co się z nami dzieje i co znajduje swoje odbicie w ich pracy, a inni byli przestraszeni i zniechęceni do wysiłków interpretacyjnych. Uznawali, że nie mają szans przeciwstawiania się neoliberalnym wpływom i że taka perspektywa zupełnie burzy szkolny porządek, w którym oni przywykli do wykonawstwa, do podporządkowania się narzucanym rozwiązaniom. Jestem nadal zdania, że brak kontaktów z nauczycielami, ta izolacja, to jest nasza wina, być może - problem, który ogranicza obydwie strony. 
K.S.: Szkoła z jakiegoś powodu zawsze ma aspiracje do bycia - mówiąc z przekąsem - „dobrze działającą maszyną”, dla której zadawanie pytań czy stawianie w wątpliwość jest zwyczajnie niebezpieczne. Taka szkoła, ze względów samozachowania, musi odcinać od siebie wszelkie kontrowersje. Wcześniej neoliberalne uwikłania, a obecnie wyraźne ruchy w równie niepożądanym kierunku. $Z$ tym że niechęć do kontaktów ze środowiskiem naukowym wynika teraz z nieco innych powodów. Również chodzi o maszynę, ale innego rodzaju, maszynę, która ma produkować odmienne efekty.

J.R.: Tak, ale jeśli weźmie się pod uwagę te etapy, to w jednym i w drugim etapie ten kontakt nie istnieje.

K.S.: Czy tylko niechęć do kontrowersji, czy coś jeszcze? Z czego wynika, zdaniem Pani Profesor, ta niechęć do współpracy między środowiskami?

J.R.: To jest coś więcej niż niechęć, to jest brak systemowych rozwiązań. Bywam bliska przekonaniu, że jest to nieprzypadkowe izolowanie nauczycieli od środowiska akademickiego. Wbrew temu stanowi jestem zdania, że nauczycielowi potrzebna jest szersza, ponadprzedmiotowa perspektywa myślowa, w jakiej on mógłby osadzać swoją codzienność. Sygnały o nowych książkach, o teoriach edukacyjnych, społecznych, wiedza o kontekstach edukacji daje nauczycielom szansę myślowego wnikania w to, co oni robią, uprawiania refleksji pedagogicznej, działania sensownego i świadomego. Mam $\mathrm{w}$ tej sprawie trochę doświadczenia, gdyż podczas moich dawniejszych kontaktów z nauczycielami zapowiadałam bez żenady, że będę referować jakąś teoretyczną myśl, najczęściej taką, jaka mogła być dla nich odkrywcza, niekiedy zdumiewająca - i to było przyjmowane. Oczywiście musiałam tę myśl ująć tak, żeby ona była dla odbiorców zrozumiała, żeby wiązała się z ich codziennością i roboczym kontaktem z uczniem. Starałam się tak to robić i to było przyjmowane.

K.S.: Mam wrażenie, że w czasie, kiedy zaczynały się krytyki neoliberalnych zmian w edukacji, kiedy zaczęliśmy zauważać co się dzieje, a Panie napisały swoją książkę, pojawiającym się krytykom przez kilkanaście lat towarzyszył marazm i brak wiary w to, że można coś zmienić. Jak to jest możliwe, że świadomości procesów towarzyszył jednoczesny brak wiary w inną rzeczywistość?

J.R.: Jest to możliwe dlatego, że - z jednej strony - potęga neoliberalizmu rośnie, a z drugiej - ciągle mamy społeczny kłopot z naszym niewysokim poczuciem sprawstwa, co powoduje, że czujemy się bezsilni wobec rzeczywistości.

K.S.: Czyli można powiedzieć, że wina $\mathrm{w}$ dużej mierze leży po stronie edukacji i szkoły? Nie chodzi mi w tym momencie o problem wdrażania do 
racjonalności neoliberalnej, czy o wymuszanie działania wedle racjonalności neoliberalnej na szkolnych aktorach, ale o brak realizacji jednego z podstawowych zadań edukacyjnych - wyrabiania poczucia sprawstwa, a dokładniej rzecz ujmując, sprawstwa w innych obszarach poza rynkowym.

J.R.: Ale jak szkoła ma dawać poczucie sprawstwa, jeśli rdzeń jej obecnej filozofii polega na tym, żeby wyposażyć ludzi w zasób informacyjny, nie w wiedzę, tylko w zasób informacyjny, który będzie reprodukowany testowo, mierzony metodami ilościowymi i który będzie podstawą standardowej kariery ucznia w systemie oświaty i w życiu. Pośrednio przyświeca temu idea maksymalizacji wszelkich zysków. To jest podstawowe założenie szkoły neoliberalnej, a wyłamywanie się spod tego założenia jest dla szeregowego nauczyciela naprawdę szalenie trudne. Pomimo to słyszy się niekiedy o nauczycielach, którzy próbują łączyć nauczanie odtwarzające z rozwijającym. Rozdarcie między tymi tendencjami tworzy obszar nauczycielskiego dramatu.

K.S.: Z jednej strony bez wątpienia towarzyszy nam brak poczucia sprawstwa, który wyłącza wyobraźnię i chęć do działania. Z drugiej jednakże, od 2008 roku, a więc wielkiego tąpnięcia hegemonicznego dyskursu, wywołanego przez kryzys ekonomiczny, jakiegoś rodzaju zmiana się jednak dokonała. Mówię tu o widocznym wyłomie w dyskursie neoliberalnym, który można porównać do łamania się supremacji dominującego paradygmatu. Myślę tu o fenomenie ruchów takich jak Occupy Wall Street, subtelnej, ale widocznej zmianie myślenia wśród niektórych czołowych ekonomistów, aktualnej popularności myśli marksistowskiej, czy odrodzeniu lewicy. W przypadku ostatniego, nawet jeśli towarzyszy temu konserwatywny backlash, lewica stała się silniejsza. Myślenie lewicowe stało się w niektórych środowiskach modne, a w każdym razie bardziej popularne niż było jeszcze dziesięć lat temu. Teoria Karola Marksa jest w tym momencie jedną z podstawowych teorii, służących opisowi współczesnych i przeszłych procesów społecznych, wskazujących na kierunek i logikę możliwych i pożądanych zmian. Widać to nie tylko w środowisku akademickim, ale również politycznym, czy w środowisku elit symbolicznych. Wydaje się, że powoli do głosu dochodzi pokolenie, którego intelektualne dojrzewanie przypadło na okres krytyki neoliberalizmu. Zmienił się nie tylko język, ale również przedmiot naturalizacji. Innymi słowy, krytykowanie neoliberalizmu stało się czymś całkowicie naturalnym. Pani Profesor wspomniała, że książka Neoliberalne uwikłania edukacji wywoływała niegdyś zaskoczenie, zdziwienie, i w końcu wyraźnie manifestowaną niechęć do myślenia w proponowanych kategoriach. W tym momencie sytuacja jest zgoła odmienna. Zmiana języka dokonała się zarówno w sferze politycznej, jak i społecznej, pozwalając przynajmniej części młodych ludzi na wyartyku- 
łowanie doświadczenia neoliberalnego wyzysku. Zmiana się zatem dokonała. Problemem jest natomiast kierunek zmian - o czym, mam nadzieję, jeszcze trochę powiemy.

J.R.: Ja chciałabym być optymistką w tej sprawie, ale widzę, że neoliberalizm nadal jest potęgą, jako idea i jako praktyka. Zwraca się on do koncepcji potrzeb, ciągle te potrzeby wytwarza, rozbudowuje, rozpala - o czym już dawno wiemy od J. Baudrillarda - i zarazem pielęgnuje zasadę dbałości o zachowanie rozziewu pomiędzy pragnieniem a zaspokojeniem, a dokładnie - niezaspokojeniem. Bodajże tutaj tkwi jedno ze źródeł jego siły, ponieważ w ten sposób wznieca nadzieje u ludzi, nie tylko najbiedniejszych, ale również znajdujących się w dobrej sytuacji, która może być jeszcze lepsza. I ten mechanizm działa. Oczywiście jest też inne myślenie, interesujące są brazylijskie pomysły demokracji ekonomicznej L. Dowbora, ale wyniki ostatnich wyborów tak zmieniły realia Brazylii, że ruchy prodemokratyczne wydają się obecnie mało możliwe. U nas pisze się trochę o społecznej gospodarce rynkowej, ale to wszystko wymagałoby od ludzi pewnej powściągliwości, skromności i ograniczenia własnych pożądań, albo lepiej - reorientacji własnych motywacji. Tymczasem neoliberalizm niesłychanie rozpalił pragnienia, pożądania i chęć posiadania, rywalizację, zachłanność i maksymalizm, co wywołuje pytanie, jak wiązać te tendencje: samoograniczenia i maksymalizacji zaspokojenia potrzeb nierzadko sztucznie wytwarzanych.

K.S.: Jeśli mogłabym się nie zgodzić. Mam wrażenie, że konieczność samoograniczania jest $\mathrm{w}$ istocie stałym elementem doświadczenia neoliberalnej opresji. Jest to zatem problem, który dotyka całej rzeszy ludzi, zwłaszcza młodych. To, jak bardzo umyka to uwadze pokolenia "transformacji”, skłonnego widzieć w młodych ofiary niepohamowanej konsumpcji raczej niż neoliberalnego jarzma, ujawniło się wyraźnie w ostatnim czasie w konflikcie, do którego Pani Profesor nawiązała, odnosząc się do Bielik-Robson i jej wypowiedzi na temat „sporu pokoleniowego" między „ojcami” a „dziećmi” transformacji. Tegoroczna nieobecność młodego pokolenia na KOD-owskich manifestacjach została prześmiewczo zinterpretowana przez „ojców” jako wyraz ignorancji (bynajmniej w sensie rancière'owskim), koncentracji na tym co prywatne, opływania w dostatek oraz nieświadomości co do zagrożeń autorytarnych i nieznajomości realiów „komuny” młodego pokolenia. Bardziej poważnie kwestię postawiła właśnie Bielik-Robson, pisząc o symbolicznym „uśmiercaniu ojców” w krytykującym neoliberalizm i transformację dyskursie „młodych”. Wszystkie te publiczne wystąpienia zostały, słusznie zresztą, odebrane jako agresywny paternalizm, związany z całkowitym brakiem orientacji w sytuacji młodych - których życie zostało dosłownie 
przeorane przez neoliberalizm - ze strony pokolenia, które na transformacji i neoliberalizmie zbudowało swoją bezpieczną, mieszczańską pozycję. Czy to „naturalny” spór pokoleniowy, czy może jakaś edukacyjna robota nie została jednak wykonana?

J.R.: Wątpię, czy jest to sprawa pokoleniowa. Sądzę, że młodzi i starsi mogą być bliscy sobie ideowo, tyle że łączyć ich mogą różne idee. Bliskość pokoleń pojawia się wtedy, kiedy widzą one potrzeby zmiany. Sądzę natomiast, że obie te grupy mają inne wyobrażenie o sposobach działania, o formach protestu. Tak to sobie wyobrażam.

K.S.: Czy istnieje $\mathrm{w}$ takim razie możliwość pogodzenia obu sposobów widzenia?

J.R.: Tak, jest przecież możliwe działanie na dwóch frontach, a może być ich więcej. Niech młodzież działa internetowo, jeżeli uważa, że to jest dobra droga, a pokolenie, które ma w doświadczeniu inne formy niech wychodzi na ulice. Moim zdaniem to można pogodzić.

K.S.: Z drugiej strony pojawiają się również zarzuty o nieadekwatność języka „młodych” - marksistowskiego właśnie, oraz nieuzasadnioną krytykę poglądów „starszych”. To zdecydowanie jest paternalizm.

J.R.: Ale młodzież jest samodzielna, ona nie pozwoli starszym na paternalistyczną dominację. Natomiast znacząca jest sprawa tworzenia jakiejś wspólnej, wielopokoleniowej płaszczyzny dotyczącej treści zmiany, dlatego trzeba wypracować język, natomiast formy działania mogą być różne. Podtrzymuję tę myśl, ponieważ sądzę, że różnorodność form może okazać się bardziej skuteczna od działań monolitycznych. Ale wielości potrzebne jest spoiwo, owa wspólna płaszczyzna, o której już wspomniałam i którą, w nawiązaniu do wcześniejszej książki Bielik-Robson, nazwę duchowością. Przekonuje mnie ta autorka, kiedy charakteryzuje duchowość jako „wszelkiego rodzaju refleksje nad miejscem człowieka we wszechświecie i jego poczuciem egzystencjalnej orientacji i sensu". Nie idzie więc o utożsamianie jej z religijnością, co się często zdarza, tylko z takim sposobem życia, który polega na uprawianiu namysłu. Wydaje mi się, że ludzie zróżnicowani pokoleniowo podejmują zbyt mało takich wspólnych namysłów. Nie bez winy jest w tej sprawie dzisiejsza szkoła, w której sprawy namysłu nad rzeczywistością zostały zepchnięte w kąt. Nie ma namysłu, są tylko informacje i ich odtwarzanie. Tymczasem nietrudno znaleźć tematy sprzyjające budowaniu wspólnotowych więzi pokoleniowych. Dostarcza ich literatura, film, życie codzienne. Ostatnio, będąc w gdańskim Teatrze Miniatura na spektaklu Wieloryb, zastrzeżonym dla dorosłych, zapytałam twórców, czy jest możliwy teatr rodzinny bez oddzielania publiczno- 
ści dziecięco-młodzieżowej od dorosłej. Odpowiedziano mi, że takie próby podejmuje się, ale nie jest to łatwe. No cóż, ważne sprawy nigdy nie są łatwe.

Muszę dodać, że w tym moim sceptycznym spojrzeniu na paternalizm wiele zawdzięczam osobistej sytuacji. Mam wokół siebie młodych ludzi, którzy są wytrwałymi dyskutantami, mają własne argumenty, poszukują uzasadnień dla swoich opinii. Odbieram codzienne lekcje demokratycznej międzypokoleniowej rozmowy i mam nadzieję, że nie jest to stan unikalny.

K.S.: Zarzuty wobec „młodych”, a więc dzisiejszych 30/40-latków jednak się pojawiają. O to, że nie próbują się zintegrować w sprzeciwie wobec działań polityków, wobec PIS-u mówiąc wprost, że mówią nieodpowiednim językiem, myślą skompromitowanymi kategoriami marksistowskimi, że brak im edukacji obywatelskiej, czy że bezmyślnie i „dziecinnie” oskarżają starszych o myślenie liberalne oraz niegdysiejsze sprzyjanie neoliberalizmowi. Innymi słowy, medialna strona opisywanego konfliktu międzypokoleniowego przybiera jakąś formę paternalizmu. Jeśli przedstawiciele KOD-u i liberalne elity symboliczne zarzucają młodym nierealistyczne i utopijne myślenie czy zabawy z marksizmem, to czy nie jest to troszkę jak paternalizm? Czy może jednak obopólny brak zrozumienia przeszłości „ojców” i teraźniejszości „młodych” oraz brak wspólnego języka?

J.R.: Ja nie dostrzegam nastrojów paternalistycznych w dużym wymiarze, ale może trzeba się lepiej rozejrzeć dookoła. Natomiast na pewno istnieje problem międzypokoleniowych powiązań. Rzecz ma szerszy wymiar - my wszyscy odwykliśmy od myślenia o naszych sprawach, traktujemy je w sposób objawowy, stereotypowy, pragmatyczny; młodzi pędzą naprzód i nierzadko odcinają się od uprawiania refleksji, traktując ją jako czynność jałową, starsi patrzą wstecz, zastanawiają się nad przeszłością i niejednokrotnie konstatują, że ich wysiłki poszły na marne, co zniechęca do bieżącego namysłu.

Wróćmy jeszcze do tych okazji do wspólnego podejmowania refleksji, a dostrzegam je - między innymi - w czytaniu literatury, w której nazywa się ważkie tematy. Niedawno zapytałam pracowników biblioteki publicznej, z której korzystam, co jest najczęściej czytane, czego czytelnik szuka? Otóż szuka kolejno - romansów, z emocjonalną fabułą i szczęśliwym zakończeniem, literatury przygodowej i biografii, po które sięga odbiorca bardziej zaawansowany. Ja interesuję się literaturą reportażową, zauważyłam, że ostatnio zaczęły ukazywać się polskie reportaże o pracy, co może być podstawą do rozmów, także i pokoleniowych. Kłopot polega na tym, że zakup biblioteczny jest uzależniony od zainteresowania czytelników, a kto interesuje się romansami ten raczej nie będzie czytał o pracy łódzkich włókniarek albo o przepracowanych Polakach. I tutaj coś się zamyka. 
Warto byłoby śledzić takie punkty adaptacyjnego zamknięcia i próbować wprowadzać do nich jakiś ruch. Tego się oczywiście nie da zarządzić, nie da się zaprojektować w dużej skali, ale właśnie w małych miejscach, chociażby w bibliotece. Ale wówczas nie może w niej dominować przystosowanie do najprostszych gustów czytelniczych.

K.S.: Pani Profesor wyraźnie mówi tutaj o zadaniu zamierzonego i intencjonalnego kształtowania jakiegoś takiego powszechnego uniwersum symbolicznego.

J.R.: Moim zdaniem edukacja jest od tego właśnie.

K.S.: Czy w takim razie za ten dostrzegalny brak wspólnej płaszczyzny nie odpowiadają w jakimś stopniu pedagodzy, których zadaniem było i jest kreowanie normatywnego myślenia o szkole, a którzy to zadanie w rzeczywistości potransformacyjnej świadomie odrzucili? Od lat 90. mówienie w kategoriach powinności stało się w pedagogice czymś wstydliwym. $\mathrm{Z}$ jednej strony, ze względu na łączenie tegoż z monodyskursem państwa socjalistycznego, $z$ drugiej, ze względu na potransformacyjną fascynację postmodernizmem. Zejście się tych dwóch podstawowych przyczyn doprowadziło zresztą do paradoksu. Wintegrowanie polityczności w rodzimą refleksję pedagogiczną łączyło się z jednoczesną niechęcią nie tyle do upolityczniania edukacji, co stawiania wobec niej zdecydowanych wymagań deontologicznych. Od niedawna dopiero, powoli, wracamy do języka powinności, widzianego teraz w kategoriach remedium na współczesne kryzysy polityczne i kulturowe. Czy ta niechęć do normatywizmu i wyznaczania uniwersalnych zadań stojących przed edukacją i szkołą nie doprowadziła nas właśnie tutaj?

J.R.: To ważne pytanie, ale nie podzielam tezy o odrzuceniu normatywności, sądzę natomiast, iż my w gruncie rzeczy przeszliśmy od normatywności do normatywności. Ta „nowa normatywność” łączy się z neoliberalnym uwikłaniem edukacji. Proszę zauważyć, wydawało się nam, że porzucimy normatywność, przejdziemy przez upadek Lyotardowskich Wielkich Narracji, i dojdziemy do wielu narracji, do wielości satysfakcjonującej nas w warunkach demokracji. Ale przecież stało się coś takiego, że upadły jedne wielkie narracje, a narodziły się inne. Moim zdaniem neoliberalizm jest wielką narracją, która się urodziła tak, że my tego nie zauważaliśmy przez jakiś czas. W tym sensie wcale nie porzuciliśmy normatywności tylko przeszliśmy od jednej do drugiej, chociaż wydawało się nam, że zeszliśmy z tej drogi.

K.S.: Od jednego narzuconego...

J.R.: ...do drugiego narzuconego. Od narzuconego do narzuconego. Tylko trzeba było to dostrzec. 
K.S.: Czy można zatem powiedzieć, że nie było u nas takiego momentu, by edukacja rzeczywiście pełniła swoją funkcję? Aby generowała taki uniwersalny projekt, uniwersalną płaszczyznę umożliwiającą porozumiewanie się zróżnicowanych grup, czy wytwarzała taki język, taką przestrzeń symboliczną, w której wszyscy mogliby się odnaleźć?

J.R.: Był taki moment, ale właśnie moment. To było na przełomie lat 80 . i 9o. Natomiast reforma szkolna z roku 1999 już zdecydowanie przypieczętowała nową normatywność. Dobry okres stanowił koniec lat 8o. i początek 90., kiedy zaczęły powstawać szkoły społeczne jako placówki rzeczywiście uspołecznione, a nie szkoły wysoko dochodowe, elitarne, w które one się później przekształciły, kiedy działało Społeczne Towarzystwo Oświatowe, żywe były inicjatywy alternatywne wobec obowiązujących rozwiązań. Reforma 1999 zamknęła ten czas, chociaż zarazem prezentacja założeń reformy nie zawierała interpretacyjnego komentarza owych założeń. Po prostu przyjęto pewne rozwiązania jakby były one oczywiste, co stanowi potwierdzenie naturalizacji sprawy. Jedyne uzasadnienia znajdowano w oświatowych doświadczeniach Zachodu, które traktowano bezkrytycznie.

K.S.: Można więc mówić o takim momencie, który nie został podchwycony, i o prześwicie, który nie znalazł kontynuacji?

J.R.: Tak, to był ładny czas i prześwit, ale krótki. Niestety, tylko prześwit.

K.S.: I w efekcie, jak mi się wydaje, doświadczamy aktualnie bardzo poważnych konsekwencji tego zaniechania. Niechęć do aktywnego generowania włączających, a niewykluczających uniwersów symbolicznych, czy niewykorzystanie prześwitów, o których mówiła Pani Profesor, w znaczącym stopniu przyczyniło się do obserwowalnych, niepożądanych zmian w przestrzeni symbolicznej. Mówię tutaj o zjawisku faszyzacji życia społecznego, które jest nowym normatywizmem, generowaniem wykluczającego i opartego na podziałach uniwersum symbolicznego. Ta niebezpieczna, aktualnie wykonywana praca w przestrzeni symbolicznej, przekłada się z kolei bezpośrednio na brutalizację życia społecznego. Pojawiają się interpretacje, które w pełni podzielam, mówiące, że to specyficzne połączenie neoliberalizmu z elitaryzmem, oraz promowanie oświeceniowego racjonalizmu przyczyniło się do prawicowego backlashu, a więc odrodzenia - przemawiającego do uczuć i emocji dyskursu narodowościowego - i ostatecznie umożliwiło faszyzację polskiej przestrzeni publicznej. Oczywiście zrzucenie całej odpowiedzialności na karb transformacji i potransformacyjnej elitaryzacji pozwala może wskazać na niektóre z przyczyn akceptacji dla dyskursu narodowościowego, ale na pewno nie daje możliwości zrozumienia przyczyn takiego wzrostu narodowościowego sentymentalizmu pod szyldem „żołnierzy wyklętych”, 
i co gorsza, fascynacji faszyzmem wśród młodzieży. Co takiego zdaniem Pani Profesor się stało?

J.R.: Zrobiła Pani duży skok, ale zgadzam się z tym rozumowaniem. Odpowiem fragmentem reportażowej książki M. Kołodziejczyka, zatytułowanej Prymityw. Epopeja narodowa. Powieść - 2018, gdzie jeden z bohaterów mówi tak: „żeby chociaż (...) jakaś drobna, ale okrutna wojna, wtenczas człowiek czuje się przydatny i nawet przypuśćmy, że odda życie we wojnę, przynajmniej będzie się dobrze czuł - że było sens żyć". Unieruchomienie ludzi wich niespełnieniu prowadzi ich do takich nastrojów, a znowu spełnianie wiąże się z pytaniem o normatywizm. To jest nieustający temat dla edukatorów.

K.S.: Tak, ale to znaczy, że edukacyjnie jakaś praca nie została wykonana. Ostatecznie też rolą edukacji, poza wytwarzaniem uniwersum włączającego, umożliwiającego zróżnicowanym aktorom wpisanie siebie w jego obręb, jest również wytwarzanie czy generowanie takich znaczeń, które dawałyby jednostkom możliwość uzyskiwania poczucia sensu i jego realizacji. Wobec ich braku jednostki zostały popchnięte do poszukiwania sensu życia czy usensawiania własnego życia i otaczającej rzeczywistości w tak radykalnej formie. Czy nie oznacza to, że szkoła zaniedbała również ten obszar funkcjonowania jednostek?

J.R.: Tak, oczywiście. Kiedy czytam reportaże o dzisiejszych Polakach, a mam na uwadze teksty autorstwa Z. Szczerka, A. Cieplak, P. Sołtysa czy książki D. Masłowskiej, widzę, że ten problem jest przez nich wręcz wynoszony. Zwrócę się jeszcze raz do bohatera Kołodziejczyka, który mówi tak: „Widocznie takie czasy (...) że potrzeba jakiegokolwiek powstania jest u nas paląca. Tylko przejściowy kłopot $\mathrm{z}$ wyborem wroga. Raczej $\mathrm{z}$ nadmiarem wrogów, spiskujących zewsząd przeciwko ludzkości, a spiskują, bo nam wszystkiego zazdroszczą. Na przykład: chleba, mięsa, węgla i kobiet”. I dalej: „Wyczuwało się podskórnie, że wpierw nastąpi u nas powstanie zbrojne przeciw, a później się ustali przeciw czemu". Teksty wypowiadane przez bohaterów świadczą o tym, że ludzie czują, iż ich życie przebiega nie tak, jakby chcieli, zresztą reportaże są pełne wstrząsających opisów takiego właśnie niechcianego życia, na bardzo niskim poziomie pod każdym względem. Zarazem bohaterowie mają trudności z nazwaniem tego, w czym uczestniczą oraz $\mathrm{z}$ nadawaniem sensów własnemu życiu, jakby w nim tonęli. Sfera uniwersum symbolicznego nie jest tutaj obecna. Łączę to ze słabością pracy edukacyjnej, kiedy nie wspomaga się ludzi w uzyskiwaniu kompetencji poddawania oglądowi swojego życia, nazywaniu jego wymiarów, projektowaniu zmian, krytycznym angażowaniu się. Tu jest duża robota do zrobienia. 
K.S.: Z drugiej jednakże strony, szkoła podchwyciła opisywane, radykalne tendencje, które zaczęły się rodzić wśród polskiej młodzieży, czy szerzej, w polskim społeczeństwie. Mówię tutaj o szkole i edukacji, która stawia sobie za cel kształtowanie postaw, eufemistycznie nazywanych patriotycznymi, a w rzeczywistości budowanych na nieodpowiednim gruncie - agresywnym, konstruującym wrogów i granice uniwersum symbolicznym, w ramach którego udana próba usensawiania własnego życia dokonuje się zawsze kosztem innych.

J.R.: Ciekawa jestem, na ile sama szkoła je podchwyciła, a na ile czuje się przymuszona do przyjmowania kierunku kształtowania postaw, o jakich Pani mówi. Rzeczywiście, jeżeli będzie wróg, jeżeli będziemy ścierać się z nim, to będzie się działo coś „wielkiego”, szczególnie jeśli poza tym nie ma czegoś wielkiego w życiu. Świetne określenie znalazłam kiedyś w pismach J. Patočki, który pisał o „skarleniu kulturalnym”. We wspomnianych polskich reportażach społecznych, a napisano ich dużo, mówi się o takim skarleniu, skarleniu całego życia - stosunków z ludźmi, pracy, sposobów myślenia, codzienności. Zarazem ludzie wiedzą, że ich życie jest kruche, więc chcą się jakoś wybić, pragną dla siebie czegoś „większego”, ale jest im trudno to „większe” znaleźć i odróżnić. Wtedy pojawiają się najprostsze, elementarne pomysły - z kimś się zetrzeć, pobić się, zmierzyć siły i tak dalej. Trzeba by zwracać uwagę na inne możliwości, podsuwać pomysły i inne projekty działań.

K.S.: Czyli wytwarzać uniwersum, które nie będzie uniwersum dzielącym, uniwersum opartym na konstruowaniu wrogów, dostarczającym znaczeń i sposobów usensawiania życia w praktyce wojennej...

J.R.: Rzecz nie tylko w propagowaniu praktyki wojennej, nie tylko w robieniu podziałów. Akcent postawiłabym na części pozytywnej, na wspomaganiu usensawiania własnego życia ludzi przez nich samych. Mieściłyby się w nim jakieś „wyższe cele”, są one wprawdzie hasłem ryzykownym, o którym chyba jednak trzeba mówić.

K.S.: Z drugiej strony, oparty na opisywanej przez Panią Profesor logice wojennej, współczesny patriotyzm, funkcjonuje właśnie jako wyższy cel. Innymi słowy, jest sposobem na stawianie wyższych celów w sytuacji, w której cele te zostały kiedyś zapomniane. Co gorsza, dyskurs ten wykorzystuje również szkoła w swojej aktualnej formie i po zmianach, jakie zaszły między innymi w obszarze edukacji obywatelskiej, która zastąpiona została edukacją patriotyczną.

J.R.: Raczej pseudopatriotyczną... 
K.S.: ...która nie staje przeciwko temu co się dzieje, ale się tym karmi, i karmi się tak niepokojącymi nastrojami społecznymi. Co wobec tego możemy zrobić?

J.R.: Jest to pytanie arcytrudne. Ale to, co mogą robić humaniści, to mówić, ponieważ język jest ich narzędziem. Przypomnę chociażby takie wydarzenie, że wiosną tego roku Oddział Polskiego Towarzystwa Pedagogicznego w Uniwersytecie Gdańskim zorganizował zebranie otwarte na temat „Uniwersytet wobec zagrożeń faszyzmu". Wywołało ono bardzo duże zainteresowanie, przyszli różni ludzie, padały różne głosy, mówiliśmy o sprawie gorącej dla wszystkich. Kiedy skończył się czas przydzielenia sali, głosy chętnych do wypowiedzi były ciągle otwarte. $\mathrm{W}$ takich zebraniach uczestniczę od lat, ale nigdy nie było tak, żebyśmy musieli kończyć spotkanie wtedy, kiedy byli jeszcze chętni do dyskusji. To potwierdza tezę, że jest zapotrzebowanie na to humanistyczne mówienie, że mówienie ciągle ma sens. Trzeba by więc uruchamiać dalsze podobne inicjatywy, uruchamiać prace językowe. Już rozpoczęto działania kontynuacyjne nad zorganizowaniem w UG, w roku 2019, cyklu projekcji filmowych o faszyzmie. To byłyby okazje do rozmów na ten napięty temat.

K.S.: Chodzi zatem z jednej strony o edukację, która dostarcza języka i z drugiej, o edukację, która dostarcza miejsca i kontekstu, w którym ten język mógłby się dopiero wytworzyć we wspólnej rozmowie?

J.R.: Oczywiście, czyli o edukację, która daje do myślenia i daje do mówienia.

K.S.: Czyli jest również szansa na to, że rewolucja, z którą obecnie mamy do czynienia - przez analogię do rewolucji neoliberalnej - nie zostanie prześniona przez pedagogów, ale będzie się wiązać i wiąże $\mathrm{z}$ ich aktywnym sprzeciwem wobec tego, co się dzieje. Nie zauważyliśmy zmian neoliberalnych aż do momentu, kiedy prawie zaczęliśmy się w nich topić. Teraz natomiast jest szansa, że jednak nie utoniemy.

J.R.: Wyraża Pani piękny optymizm, ale ja myślę, że aby nie prześnić, trzeba być wytrwałym tropicielem, który patrzy okiem szeroko otwartym. Zauważać, że w życiu są również i sny, czuwać, czy w tej chwili śnimy, czy jesteśmy w realnej rzeczywistości. Trochę obawiam się, czy nie osłabiła się zdolność do czuwania nad własnym snem i nie snem.

K.S.: W ostatnim czasie pojawiają się jednak również głosy wyraźnego sprzeciwu, nie tyle wobec upolitycznienia edukacji, ile raczej wobec języka powinności i utopijnych wizji nowego, bardziej równego i sprawiedliwego świata, a możliwego do zrealizowania za pomocą edukacji. Właśnie to „za pomocą" budzi w badaczach $\mathrm{z}$ tego nurtu największe wątpliwości. Edukacja 
„do” i „dla” to edukacja zinstrumentalizowana. Możliwość jej deinstrumentalizacji wiązana jest tymczasem z poszukiwaniem tego, co właściwe edukacji, jej autonomizacją - jak u J. Masscheleina, czy pójściem w kierunku tzw. post-krytyki i post-krytycznej pedagogiki - jak u N. Hodgson, J. Vlieghe i P. Zamojskiego. To ostatnie podejście wiązane jest z zasadą, którą wymienieni badacze opisują w kategoriach troski i ochrony - w miejsce podważania, demistyfikacji, czy skoncentrowanej na dysfunkcjonalności „transcendentalnej i utopijnej krytyki”. Czy zdaniem Pani Profesor post-krytyczną pedagogikę należałoby uznać za kolejną formę, w jakiej realizuje się polityczność edukacji, czy może jako zupełne zerwanie z językiem, w którym kategoria polityczności odgrywa istotną rolę?

J.R.: Jestem zdania, że trzeba tu zachować ostrożność. Sama idea edukacji postkrytycznej jest bardzo obiecująca, nie znaczy to, co zresztą Zamojski w swoim tekście wprost napisał, że edukacja postkrytyczna ma być niekrytyczna. To jest kluczowe dla sprawy. Same hasła troski, opieki, pozytywnych projektów... natychmiast łączą się z pytaniami - kto się troszczy, o kogo się troszczy, w jaki sposób się troszczy i ku czemu się troszczy. Takie pytania wskazują na niebezpieczeństwo upolitycznienia. Sądzę, że tu jest poważna robota do zrobienia - jak połączyć pedagogikę postkrytyczną z krytyczną i jak ciągle uprawiać krytycyzm harmonizowany z projektami pozytywnymi. Przekonują mnie takie pomysły, jak chociażby koncepcja P. Zamojskiego o nieustającej debacie wokół celów edukacyjnych. Z podobnymi pomysłami zetknęłam się w Szwecji w latach 90., gdzie uprawiano permanentną reformę szkolną. Bo to jest oczywiście złudzenie, że uda się zaproponować i zaprojektować takie stałe rozwiązania edukacyjne, które będą doskonale wyważone; zawsze są one narażone na niebezpieczeństwo upolityczniania. Zdynamizowanie kwestii, a dokładniej - zdobywanie sztuki łączenia ciągłości i zmiany, to jest jakieś wyjście. Nie mamy w tym dużego doświadczenia, ale można się czegoś nauczyć. I trzeba by się do tego dziarsko zabierać.

K.S.: Miejmy nadzieję, że tym razem staniemy na wysokości zadania. Bardzo dziękuję Pani Profesor za spotkanie oraz za niezwykle interesującą rozmowę.

\section{SUMMARY}

\section{The Background and the Movement - A Conversation on the Political in Education}

The conversation explores the political context of education and the questions of education'srelation to the political and its politicization. It is focused on the current issues such as neoliberalism, post-trust, the brutalization and the fascistic tendencies of modern political life, as well as on the historic ones such as the post-communist 
transformation. The participants discuss both the educational failures that might have contributed to the current situation as well as the perspectives for an educational theory that is socially responsible and sensitive to the political context of our societies.

KEY WORDS: education and the political, politicization of education, neoliberalism, post-communist transformation, post-truth politics 